\title{
The Influence of Political Communication Toward Public Opinion About the Victory of the Regent and Vice of the Regent of Tulungagung
}

\author{
Erna Sugiarti $^{1}$, Poppy Ruliana², Irwansyah ${ }^{3}$ \\ ${ }^{1}$ Postgraduate Student in the Communication Studies Program, InterStudi Communication Studies \\ InterStudi College, Jakarta Indonesia \\ ${ }^{2}$ Postgraduate Study Program Master of Communication Studies, InterStudi College of \\ Communication, Jakarta Indonesia \\ ${ }^{3}$ Communication Studies. FISIP. University of Indonesia, Jakarta, Indonesia \\ Corresponding Author's Email : ernasugiarti77@gmail.com
}

\begin{abstract}
The problem in this study is the development of the issue of the elected regent of Tulungagung, Syahri Mulyo, who was declared a corruption suspect by the Corruption Eradication Commission for accepting bribes related to road infrastructure development projects, and then came public opinion that was controversial. The purpose of this study was to find out and explain the influence of communication politics of public opinion about the victory of the Regent and Deputy Regent of Tulungagung. The theory of political communication is used from Dan Harold D Lasswell, developed by Dan Nimmo into elements of political communication and to measure public opinion the ABCs of Attitude theory put forward by D.W Rejecky. The approach used in this research is quantitative using survey research methods, with the intention of analyzing and explaining the causal effects between variables through hypothesis testing. The population in this study are all residents of Tulungagung Regency who are at least 17 years old or already have a KTP or are married. While the number of samples involved 400 respondents. Data collection is done by direct interviews with respondents through questionnaires, field observations, documentation and literature and internet studies in order to obtain relevant information and data. Data analysis uses simple regression analysis to determine the effect of political communication on public opinion. The results showed that there was a strong influence of political communication on public opinion about the victory of the Regent and Deputy Regent of Tulungagung. The findings in this study are interpersonal communication and public belief, if one day Syahri Mulyo will be re-elected as regent of Tulungagung Regency
\end{abstract}

Keywords: political communication, opinion, public, public opinion

\section{INTRODUCTION}

Election of Regional Head (Pilkada) is a democratic process to elect officials who will be leaders in an area in accordance with the mandate of article 56 of Law Number 32 Year 2004 concerning the election of Regional Heads and 
Deputy Regional Heads who are elected in pairs. which is carried out democratically based on the principle of direct, public, free, confidential and honest. This election is held simultaneously in accordance with the mandate of the 2016 Regional Election Law in article 201 clause 3 which states that simultaneously voting in the election of the Governor and Deputy Governor and the Regent and Deputy Regent and Mayor and Mayor and Mayor and Mayor and Deputy Mayor are serving their term ends in 2018 and 2019 held on the same date and month in June 2018. The main purpose of the selection of Regional Heads is to invite the public to elect regional head candidates according to their conscience. There are four pillars to choose regional leaders, namely the first pillar, integrity. The basis of integrity is ethical character and behavior. He plays on the moral aspects and personal nature. The second pillar, ability. In the realm of management, capability is a combination of motivation, knowledge and skills. People who have the ability means people who understand and are experts in their field of work. The third pillar, authority. As the name suggests, authority is a position of authority based on formal legality. The purpose of authority is to encourage the organization. It also includes tools to enforce discipline and regulation. The fourth pillar, caritas. This is now a popular phrase that a leader is a servant who has the humble and respectful nature of others. Position is a mandate and therefore the mandate must be accountable to its constituents by serving wholeheartedly for them. (on kompas.com webpage, $6 / 28 / 2018)$

Along with simultaneous elections in 2018, the dynamics of political communication in our country are becoming increasingly lively with news in the mass media and online media related to activities surrounding the implementation of election campaigns. The dynamics of political communication every individual has the right to communicate or freedom of opinion. According to Bill Kovach and Tom Rosenthiel (in Haryanto, 2010), "the right to information is a basic right inherent in humans, or as human consciousness to know things outside themselves". In government administration, the right to communicate is often associated with political communication or delivery of messages to the public or people who have a policy of state power. Related to political dynamics, Syahri Mulyo and Maryoto Bhirowo (SaHto) as political communicators supported by the Indonesian Democratic Party of Struggle and the National Democratic Party nominate themselves as Regents and Vice Regents of Tulungagung which eventually won by 322,577 votes or 61.30 percent. KPU Tulungagung ratified the recapitulation of the results of the vote count in Tulungagung Regency Pilbup 2018. The determination of the vote count was issued by the KPU through decision letter number 123 / HK.03.1-Kpt / 3504 / KPU. Kab / VII / 2018. Chairperson of the Election Commission Tulungagung Suprihno said in this determination all witnesses from both pairs of candidates raised objections to the results of the vote recapitulation by the KPU. 18). The decree explained that the Sahto pair (Syahri Mulyo-Maryoto Birowo) won absolutely in 17 districts out of a total of 19 districts. (in page detik.news, July 5, 20) 
Syahri Mulyo's victory in the election of the Tulungagung Regent in the period 2018-2023 is inseparable from the role of volunteers consisting of cadres supporting the party, namely PDIP and Nasdem, as well as the wider community who organize themselves. A large number of these volunteers surpassed the party winning team. Volunteers have 12,800 witnesses, while a party with only 3,000 people Syahri Mulyo is able to defeat the Chairperson of the Indonesian Journalists Association (PWI) namely Margiono with a large vote difference (on the tempo.com webpage, June 28, 2018). This shows that the contents of the message delivered by Syahri Mulyo and Maryoto Bhirowo regarding the vision, mission and programs are in accordance with the needs and interests of the people of Tulungagung Regency, such as a number of excellent programs namely free school uniforms, Dr. Regional Iskak The achievement of hospitals that reach internationally, and meet the basic needs of the community is a major problem that is launched every day. Besides that, Syahri Mulyo's profile is popular and is an expert in communicating with the public. (on the site Tempo.com, 28 June 20180. Previous research conducted by Susanto on the Dynamics of Political Communication in the General Election (2013) states that in political communication, the most realistic fact to be used as a measure of success in delivering messages, is the increasing number audiences who agree on what message is conveyed, the addition of followers and the number of hearings can be formed through opinions formed by political communicators, in this case the pair of Regent and Deputy Regent of Tulungagung has a strong influence in the eyes of the wider community. In addition, the results of previous research conducted by Raden Mas Jerry Indrawan (2017: 171) that political communication by political elites will not run optimally without the formation of public opinion. The popularity of political candidates will not increase if it is not supported by significant public opinion towards them, therefore, political communication and opinion the public has a relationship y ang tight because they both support each other.

Another problem arose, Syahri Mulyo was declared a corruption suspect by the Corruption Eradication Commission (KPK) for accepting bribes related to road improvement infrastructure development projects (detik.news, 2018). However, the elected regent Syahri Mulyo had received permission from the KPK to attend his inauguration as the elected regent of Tulungagung and only enjoyed half an hour as the Tulungagung Regent because the Acting Acting Regent was then handed over to the Deputy Regent, Mayoto Birowo.

Kirim HK.03.1-Kpt / 3504 / KPU. Kab / VII / 2018. Chairperson of the Election Commission Tulungagung Suprihno said in this determination all witnesses from both pairs of candidates raised objections to the results of the vote recapitulation by the KPU. 18). The decree explained that the Sahto pair (Syahri Mulyo-Maryoto Birowo) won absolutely in 17 districts out of a total of 19 districts. (in page detik.news, July 5, 20)

Syahri Mulyo's victory in the election of the Tulungagung Regent in the period 2018-2023 is inseparable from the role of volunteers consisting of cadres 
supporting the party, namely PDIP and Nasdem, as well as the wider community who organize themselves. A large number of these volunteers surpassed the party winning team. Volunteers have 12,800 witnesses, while a party with only 3,000 people Syahri Mulyo is able to defeat the Chairperson of the Indonesian Journalists Association (PWI) namely Margiono with a large vote difference (on the tempo.com webpage, June 28, 2018). This shows that the contents of the message delivered by Syahri Mulyo and Maryoto Bhirowo regarding the vision, mission and programs are in accordance with the needs and interests of the people of Tulungagung Regency, such as a number of excellent programs namely free school uniforms, Dr. Regional Iskak The achievement of hospitals that reach internationally, and meet the basic needs of the community is a major problem that is launched every day. Besides that, Syahri Mulyo's profile is popular and is an expert in communicating with the public. (on the site Tempo.com, 28 June 20180. Previous research conducted by Susanto on the Dynamics of Political Communication in the General Election (2013) states that in political communication, the most realistic fact to be used as a measure of success in delivering messages, is the increasing number audiences who agree on what message is conveyed, the addition of followers and the number of hearings can be formed through opinions formed by political communicators, in this case the pair of Regent and Deputy Regent of Tulungagung has a strong influence in the eyes of the wider community. In addition, the results of previous research conducted by Raden Mas Jerry Indrawan (2017: 171) that political communication by political elites will not run optimally without the formation of public opinion. The popularity of political candidates will not increase if it is not supported by significant public opinion towards them, therefore, political communication and opinion the public has a relationship y ang tight because they both support each other.

Another problem arose, Syahri Mulyo was declared a corruption suspect by the Corruption Eradication Commission (KPK) for accepting bribes related to road improvement infrastructure development projects (detik.news, 2018). However, the elected regent Syahri Mulyo had received permission from the KPK to attend his inauguration as the elected regent of Tulungagung and only enjoyed half an hour as the Tulungagung Regent because the Acting Acting Regent was then handed over to the Deputy Regent, Mayoto Birowo.

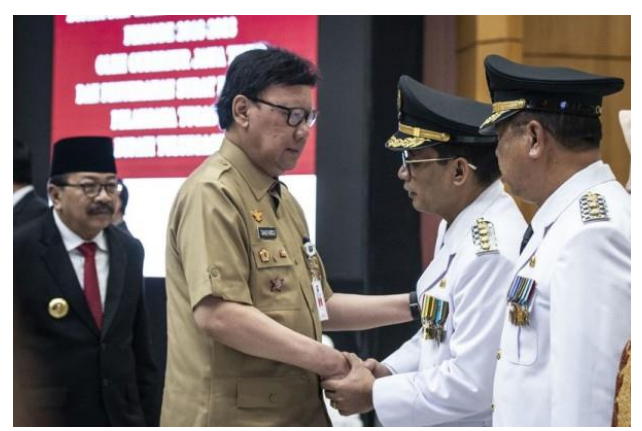

Photo 1: Inauguration of the Regent and Deputy Regent of Tulungagung 
This fact raises positive and negative opinions in the community about this case, from the positive side they consider the personal figure of Syahril Mulyo who is populist and considered successful in carrying out the leadership of the Tulungagung Regent when he took office, and not a few residents were marginalized, especially women who cried. . They still have confidence if the district head is trapped in a corruption case, and one day he will lead Tulungagung again (on the web page kompas.com, 28 Jini, 2018). In addition, judging by his achievements, Syahril Mulyo was awarded the Satya Badge for Development in the 2017 Cooperative Sector in Makassar, before receiving the 2016 Agricultural Development Satya Badge in Namgroes Aceh Darusalam (NAD). This award was also given directly by Indonesian President Joko Widodo. From the negative side, Syahril Mulyo is a corruptor who is proven guilty, now Syahril Mulyo's achievements have disappeared because of this case (on the Tegar.News website, June 8, 2018).

Apart from the problems faced by Syahri Mulya, as a political communicator has succeeded in forming public opinion as the influence of the political communication strategy carried out. Success in forming public opinion is the key to public formation in political communication, given that public opinion is very sensitive to issues that concern the interests felt by the wider community, of course the role of mass media and interpersonal communication plays an important role in winning the election of Regent and Deputy Regent Tulungagung. Mass media, such as print, electronic and online media play an important role in spreading political messages in the form of publications or news that can reach heterogeneous target audiences. This is consistent with the results of previous research conducted by Eko Susanto (2013) which states that the use of mass media such as print media, electronic media and online media, is effective for spreading political messages so that they can reach heterogeneous and very broad target audiences. this function, the media is able to supply the information needs of the audience.Other studies conducted previously by Raden Mas Jerry Indrawan (2017) show that in this digital age the media is the most effective way to shape public opinion, besides that public participation and involvement in politics is also influenced by the process of political communication and public opinion circulating among them, quoting Bernard Henessy's opinion (in Susamto, 2013), the mass media does have the responsibility to always provide true, accurate and reliable information, programs and broadcasts. Interpersonal communication

Based on the description above, the purpose of this study is to find out and analyze the influence of political communication on public opinion about the victory of the Regent and Deputy Regent of Tulungagung 


\section{LITERATURE REVIEW}

\section{Political Communication}

The study and practice of political communication focuses on ways and means of expression that are political in nature. Robert E. Denton and Gary C. Woodward, (in Arifin, 2007). two important contributors in the field of Political Communication in America describe political communication as a means and purpose of sending messages to influence the political environment. This includes public discussions (eg political speeches, news media coverage, and public talks) that consider who has the authority to impose sanctions, the allocation of public resources, who has the authority to make decisions. According to them, "" important factors that make communication 'political' are not the source of the message, but the content and its purpose. " By focusing on political messages as formal objects in Political Communication Science, discussions about politics are mechanistic, namely who speaks politics, what is said, through what channels, to whom to talk, and how they are affected. This according to Arifin (2007) follows the Lasswell formula namely Who, Says What, in Where the Channel, to Whom, With What Effect. This formula is then explained by Nimmo (in Arifin, 2007) about the elements of political communication. The elements of political communication consist of: political communicators of political messages, political channels or media, political audiences / targets and political effects. These five elements are functionally correlated and are the answers to the questions asked. (in Ruliana, 2016).

Political communicators according to Dan Nimmo (in Haidir Fitra Siagian, 2012), identified three categories of political communicators, namely: Politicians who act as political communicators. Politicians are people who spend all their time on political activities. Professional communicators in politics. A professional communicator is a symbol broker, someone who translates community attitudes, knowledge, and interests. A part time activist or communicator. Part-time communicator activists are those in organizations and interpersonal who are bound by a network of media commands. Opinion leaders can also be categorized as political communicators because they are quite respected and respected. Many citizens who are expected to make political decisions (such as electing potential leaders) seek guidance from people they respect. He can influence the decisions of others. Like politicians, they can also convince others to think and act the same as him.

Political messages were shared by Nimmo (in Arifin, 2007) in four types, namely (1) convincing and arousing the masses; (2) social authority; (3) persona expression; (4) public discussion. Political talks are aimed at the audience (audience) as a target through the mass media or channels with the aim of creating positive public opinion. The mass media or channel is a tool used to convey political messages, the most important political effect in political communication is the formation of positive public opinion and victory in elections 


\section{Opinion}

William Albig stated that opinions are expressions and controversial topics (in Arifin, 2007, Iswandi, 2018). While Robert E. Lane stated that "... opinions are answers given to questions in certain situations ..." later, William Albig defined "opinion is any expression on a controversial topic" (in Iswandi, 2018). Meanwhile according to Astrid Sunarjo (1984: 31) opinions, attitudes, and behaviors, cannot be separated. Thus it can be said that opinions are expressed statements that can be spoken with words can also be spoken with movements or other ways that contain meaning and can immediately understand their meaning. So opinions can be understood as a public problem so they experience a process in humans which can be called an attitude. - Ireland and Protho (in Arifin, 2007) state that statements that have undergone a process of communication are called opinions, whereas feelings or thoughts that have not yet been stated are attitudes. opinions that have been stated according to Doob (in Iswansi, 2018), are called actual opinions, whereas feelings and thoughts are called latent opinions. Lasswell actually believes that the opinions expressed are called external opinions, while thoughts that have not been stated are called internal opinions (Iswandi, 2018)

\section{Public}

In the context of political communication, the public can be distinguished from the masses, in terms of "awareness and interests". the public is considered to have a directed purpose, a view of the problem in determining attitudes, as well as in determining choices. Arifin (2007) states that the public can be interpreted as a mass media audience. The public can be understood as a group of people who pay attention to issues raised through the mass media and participate in an intensive discussion process to find ways to solve problems faced for the public or public benefit. According to A. Lawrence, the community is only a group that has enough attention and knowledge to adjust the problem and not the opinion of the majority. Rousseou defines the public or the public as the whole society by adhering to the principle of direct democracy (in Arifin, 2007) (3) persona expression; (4) public discussion. Political talks are aimed at the audience (audience) as a target through the mass media or channels with the aim of creating positive public opinion. The mass media or channel is a tool used to convey political messages, the most important political effect in political communication is the formation of positive public opinion and victory in elections

\section{Public opinion}

According to Arifin (2007) and Iswandi (2018) states that public opinion as a political effect is formed through a process of political communication that starts from the opinions of each individual. Thus public opinion can be interpreted and understood as a statement of controversial issues and opinions must be expressed so that they can be responded to by the public through a process of political communication and according to the author there will eventually be public opinion. 
This was according to Kasali (in Iswandi, 2018) because the development of individual opinions became public opinion, both supporting and opposing in broad outline through the time process; coverage (public area); past experience; figures (actors) and mass media as forming public opinion. Every political message or conversation that touches an individual can be rejected or accepted, generally through the process of forming understanding and knowledge, forming attitudes and opinions to approve or disapprove and the movement of implementation (Iswandi, 2018).

Based on the understanding of opinions as explained above, public opinion is a collection of individual views, attitudes, and beliefs about a particular topic, expressed by a significant proportion of a community. Whereas public opinion according to James Brice (2011), is a group of opinions about a group of people / community / community about an event or event or anything that attracts attention and becomes the subject of discussion, regarding an event, case or problem. Anwar Arifin (2011) further stated that public opinion is the same opinion and expressed by many people, which is obtained through intensive discussion as an answer to questions and problems that concern the public interest. The problem is widespread through the mass media. Public opinion is basically the opinion of the average individual in society as a result of the discussions mentioned earlier, to solve problems, especially those circulating in the mass media.

The process of opinion formation according to D. W. Rajeki (in Iswandi, 2018) public opinion has three components known as ABC of Attitude,: 1. Component A: Affection (feeling or emotion). This component is related to feeling happy, like, love, fear, hate and so on. Then the affective component is an evaluation based on one's emotions (emotional aspects) to produce good or bad judgment. 2. Component B: Behavioral This component is more displaying someone's behavior or behavior, for example reacting to hit, destroy, accept, reject and so on. So it is a component to actively move someone to take action or behave in the reaction they experience. Component $\mathrm{C}$ : Cognition (understanding or reason). This component of cognition is related to a person's choice to evaluate information, messages, facts, and understanding related to their stance. 


\section{Research Framework}

\begin{tabular}{|c|c|}
\hline $\begin{array}{l}\text { Political Communicator } \\
\text { (X1.1) }\end{array}$ & Efek \\
\hline $\begin{array}{l}\text { Political Messages } \\
\text { (X1.2) }\end{array}$ & $\begin{array}{l}\text { Afection }\left(\mathrm{Y}_{1}\right) \\
\text { Behavioral }\left(\mathrm{Y}_{2}\right)\end{array}$ \\
\hline $\begin{array}{l}\text { Political Channels or } \\
\text { Media (X.1.3) }\end{array}$ & Cognition $\left(\mathrm{Y}_{3}\right)$ \\
\hline Audience (X1.4) & $\begin{array}{l}\text { Public Opinion } \\
\text { (Y) }\end{array}$ \\
\hline $\begin{array}{l}\text { Political } \\
\text { Communication }(\mathrm{X}))\end{array}$ & DW Rejecky \\
\hline
\end{tabular}

Based on the above research framework, the independent variable (X) consists of five dimensions namely political communicator with credibility indicator is Credibility is a set of communicative perceptions about the communicator's traits. In this definition there are two things: (1) Credibility is a communicative perception, not inherent in the communicator; (2) Credibility relates to the nature of communicators, which one will later refer to as components of credibility. Because credibility is a matter of perception. Credibility changes depending on the communicator's perception, the topic discussed, and the situation. (Grace, 2008).

Then attraction Attraction (attractiveness) is the attraction of the communicator that comes from the physical. A communicator will have the ability to change attitudes through the mechanism of attraction (physical), for example, the communicator is favored or admired which allows the communicator to accept satisfaction the third indicator is power is the ability to cause submission. Like credibility and attraction, submission arises from interactions between communicators and communicators. (Grace, 2008 :).

Power causes a communicator to "force" his will on others, because he has very important resources (critical resources) (Rachmat, 2008). Political messages are political messages that are statements that are delivered, both in writing and in writing, both verbally and nonverbally, hidden or openly, both consciously and unconsciously, which contain political contents. For example speech politics, political statements, books, brochures and newspaper news about politics, etc.

Political channels or media are tools or means used by communicators in conveying political messages. For example print media, electronic media, online media, outreach, group communication by parties, community organizations, 
Political Targets are members of the community who are expected to provide support in the form of voting for parties or candidates in the General Election. They are businessmen, civil servants, laborers, youth, women, students, and the like. The expected effect of political communication is the creation of an understanding of the government system and political parties, the activeness of the community in political participation, which will later have an impact on voting in the General Election (Rachmat, 2008)

According to DW Rejekcy, public opinion consists of three dimensions namely Affection, indicators of affection are feelings of happiness, love, love, fear, hate and so on based on one's emotions (emotional aspects) to produce good or bad judgment Behavioral indicators are reacting to hit, accept and reject. Cognition, indicators related to a person's choice to evaluate information, messages, facts, and understanding related to their stance.

\section{Hypothesis}

H0: There is an Influence of Political Communication on Public Opinion about the Victory of the Regent and Deputy Regent of Tulungagung

Ha: There is no influence of political communication on public opinion about the victory of the Regent and Deputy Regent of Tulungagung

\section{METHODOLOGY}

The approach in this research is quantitative, while the method used in this study is a survey, which is commonly used in social science research because the investigation conducted is to obtain facts and symptoms or phenomena that exist as well as information about existing variables. factually checked. Kerlinger (1973) suggests survey research is research conducted on large and small populations but study data from samples taken from this population, so that relative events, distribution, and relationships between sociological and psychological variables are found. Then based on the level of explanation, this research can be grouped into descriptive, comparative and associative. In this study the authors classify the associative level of explanation (relationship) which aims to determine the relationship between the two variables because this study according to Sugiyono (2004) has the highest level if compared to descriptive and comparative research. Sugiyono (2004) also said that there are at least two connected variables and there are three forms of relationship between variables, namely symmetrical, causal and interactive. Researchers take the form of a causal relationship that explains the causal relationship, if X then Y. Furthermore Singarimbun (2006) states that the use of this method not only illustrates concepts and facts, but intends to analyze and explain the causal effects between variables through hypothesis testing.

Explanatory surveys can reveal how much political communication has influenced public opinion about the Regent and Deputy Regent in Tulungagung. In 
this study, the questionnaire was used as the main information through interviews, observations, and documentation. The population in this study are all residents of Tulungagung Regency who are at least 17 years old or already have a KTP or are married. The sampling technique used was multi stage random sampling, researchers looked at districts and villages in heterogeneous groups and individuals in RT / RW systematically randomly drawn. Determination of the number of samples using the formula Taro Yamane $\mathrm{n}=((\mathrm{N} / 1)) /\left(\left(1+\left(\mathrm{N} . \mathrm{d}^{\wedge}{ }^{2}\right)\right)\right)$, obtained a total sample of 400 respondents spread across 4 districts and 8 villages. Data collection was done by direct interviews with respondents through questionnaires. In addition, observations, documentation and literature and internet studies were carried out. Data analysis uses multiple regression analysis. The independent variables are political communicators (X1.1), political messages (X1.2), political channels (X1.3) and communicants (X14), the dependent variable is public opinion

\section{RESULTS AND DISCUSSION}

\section{RESULTS}

The theory underlying this research is the theory of political communication from Dan Nimmo which divides communication into elements of communication, namely political communicators, political messages, political media, political communicants ,. while the measurement of public opinion refers to DW Rejecky's opinion with the ABC's of Attitude theory, namely affection, behavioral and cognition as the effects of political communication.

The results of the research that will be presented in the following discussion include four parts, namely: (1) Description of respondent data that will describe the characteristics of respondents as well as data from each research variable based on their size and distribution; (2 validity and reliability; (3) Hypothesis testing that discusses the processing and analysis of data to empirically explain the relationship between research variables. (4) Discussion of research results. Following is a description of the data for each research variable:

\section{Description of Respondent Data}

Based on data from the number of respondents in each village in Tulungagung District, 11 respondents (11\%) in Bungur village, 8 respondents $(8 \%)$ in Kjeli village, 14 respondents $(14 \%)$ in Gesikan village, 8 respondents $(8 \%)$ in Gombang village , 16 respondents (16\%) in Junjung Village, 16 respondents (16\%) also in Sumberdadi Village, 15 respondents (15\%) in Bago Village, and 12 respondents (12\%) in Kepatihan Village. Seeing the distribution of respondents is quite representative because it has a relatively equal amount. The distribution of respondents is in accordance with the allocation of respondents who have been determined. Determination of the allocation of respondents in each region based on proportional number of Permanent Voter List (DPT) in the election of the regent of 
Tulungagung Regency in 2018. So in this case the sample taken is able to represent the population or representative.

Description of data on the identity of respondents such as gender, age, occupation and education level, the results show male respondents are equal to the number of female respondents, each 50\%. This is in accordance with the real condition of the proportion of men and women in Tulungagung Regency. Viewed from the age, most respondents aged 30-39 years by $27 \%$, then $20-29$ years $22 \%$ and at least $8 \%$ of respondents aged greater than 60 years. The Tulungagung community makes the most lives as farmers $32 \%$, entrepreneurs $23 \%$, private employees $11 \%$ and the rest are civil servants, honorary teachers, professionals and others. Based on the level of education, the most respondents were high school graduates by $43 \%$, then junior high school graduates $28 \%$ and only $1 \%$ completed S2 / S3.

\section{Validity and Reliability of Research Instruments}

The results of validity testing show all items on the variables used in this study include political communicators, political messages, political channels, audiences and public opinion are valid, because they have a significance value < of 0.05 and tcount $>\mathrm{t}$ table that is equal to 1.687 . While the reliability test results of each dimension on the independent variable and the dependent variable show a reliable number. The instrument reliability criteria are having a Cronbach alpha value greater than 0.6. The alpha cronbach value of the dimensions of political communicators, political messages, political channels, audiences and public opinion are respectively $0.84,0.88,0.62,0.72$ and 0.81 .

\section{Hypothesis Testing That Discusses Data Processing and Analysis to Explain Empirically the Relationship Between Research Variables}

\section{Correlation Analysis}

Correlation analysis is intended to measure the close relationship between two variables. Correlation values range from -1 to 1 . Correlations close to -1 or 1 indicate a perfect correlation between the two variables. While correlations approaching 0 indicate a low relationship. The result, obtained correlation values $\mathrm{X} 1.1, \mathrm{X} 1.2, \mathrm{X} 1.3$ and X1.4 against $\mathrm{Y}$ respectively $0.63,0.62,0.54$ and 0.62 . The correlation value, shows a fairly strong relationship between X1.1, X1.2, X1.3 and $\mathrm{X} 1.4$ to $\mathrm{Y}$. This condition, indicates there is a causal relationship between the independent and dependent variables. One analysis technique for estimating causality is regression analysis. So that will be followed by multiple linear regression analysis. 


\section{Testing the Classical Assumptions of the Multiple Regression Model}

The classic assumption test of multiple linear regression models is performed on the error of the regression model to test normality, non-heteroscedasticity and multicollinearity. First, the normality test results show the value of sig. $=0.076>$ 0.05 , then don't reject $\mathrm{H} 0$. That is, the error of the regression model spread normally. Second, the non-heteroscedasticity test is carried out using a plot between the dependent variable and the standard residual, the results show the plot is spread randomly or does not form a certain pattern. That is, there is no heteroscedasticity or constant model errors. Third, the multicollinearity test shows the value of the Political Communicator Variance Influence Factor (VIF) of 5.37, Political Messages of 4.29, Political Channels of 1.66, and Communications of 2.87. The four indicators show numbers smaller than 10 , so don't reject $\mathrm{H} 0$. That is, there is no correlation between independent variables. Thus, it can be concluded that there was no violation of the classical assumptions in the regression model error.

\section{Estimation and Testing of Regression Coefficients}

The results of the calculation of estimation and testing of the regression coefficients are listed in Table 1, the regression model developed is:

$$
Y^{\wedge}=6.73+0.96 X \_11+0.37 X \_12+1.44 X \_13+2.86 X \_14
$$

Table 1. Estimation and Testing of Regression Coefficients

\begin{tabular}{|c|c|c|c|c|c|c|c|}
\hline \multirow[t]{2}{*}{ Model } & \multicolumn{2}{|c|}{$\begin{array}{l}\text { Unstandardized } \\
\text { Coefficients }\end{array}$} & \multirow{2}{*}{$\begin{array}{l}\text { Standardized } \\
\text { Coefficients } \\
\text { Beta }\end{array}$} & \multirow[t]{2}{*}{$\mathrm{t}$} & \multirow[t]{2}{*}{ Sig. } & \multicolumn{2}{|c|}{$\begin{array}{l}\text { Collinearity } \\
\text { Statistics }\end{array}$} \\
\hline & B & Std. Error & & & & Tolerance & VIF \\
\hline 1 (Constant) & 6.733 & 2.947 & & 2.285 & .023 & & \\
\hline $\begin{array}{l}\text { Politic } \\
\text { Communicator }\end{array}$ & 959 & 167 & .253 & 5.735 & .000 & 186 & 5.369 \\
\hline Politic Messsgae & .365 & .148 & .097 & 2.461 & .014 & .233 & 4.286 \\
\hline Politc Cha & 1.436 & .161 & 220 & 8.92 & .000 & .594 & 1.685 \\
\hline Audience & 2.862 & .183 & .505 & 15.672 & .000 & .348 & 2.870 \\
\hline
\end{tabular}

Based on Table 1, we get the sig value of constant 0.023 and $t$ arithmetic $=$ 2.285 while $t$ table $=1.96$, because the value of sig $\langle 0.05$ and $t$ arithmetic $\rangle t$ table then the constant is declared significant. Variable X11 obtained sig $=0.000$ and $t$ arithmetic $=5.74$ while $t$ table $=1.96$, because sig $<0.05$ or $t$ arithmetic $>\mathrm{t}$ table means that there is a significant influence of the political communicator variable (X11) on public opinion (Y). It can be concluded, there is a significant influence of the independent variable of political communicator X11 on the dependent variable of public opinion $\mathrm{Y}$ in Tulungagung Regency at a real level of 5\%. The level of trust regarding the influence of political communicators on public opinion is listed in Table 2, obtained a coefficient of determination of 0.736 . This means that $74 \%$ of the average diversity of public opinion can be explained by political communicators, while the rest are other factors that have not been included in the 
regression model.

Table 2 Coefficient of Determination of Political Communicators on Public Opinion

\begin{tabular}{ccccc}
\hline Model & R & R Square & Adjusted R Square & Std. Error of the Estimate \\
\hline 1 & $.858^{\mathrm{a}}$ & .736 & .735 & 4.103 \\
\hline
\end{tabular}

The political message variable X12 obtained the value of sig $=0.014$ and $\mathrm{t}$ arithmetic $=2.46$ while the $t$ table $=1.96$, because the value of sig $<0.05$ or $t$ arithmetic $>\mathrm{t}$ table means that there is a significant influence of the political message variable (X1.2) on public opinion (Y). It can be concluded, there is a significant influence of the independent variable of political messages on the dependent variable of public opinion in Tulungagung Regency at a real level of 5\%. The level of confidence regarding the influence of political messages on public opinion is listed in Table 3, obtained a coefficient of determination of 0.637 . This means that $64 \%$ of the average diversity of public opinion can be explained by political messages, while the rest are other factors that have not been included in the regression model.

Table 3 Coefficient of Determination of Political Messages Against Public Opinion

\begin{tabular}{ccccc} 
Model & $\mathrm{R}$ & R Square & Adjusted R Square & Std. Error of the Estimate \\
\hline 1 & $.798^{\mathrm{a}}$ & .637 & .636 & 4.811 \\
\hline
\end{tabular}

The political channel variable X13 obtained sig $=0,000$ and $t$ arithmetic $=8,922$ while $\mathrm{t}$ table $=1.96$. Because the value of sig $<0.05$ or $\mathrm{t}$ arithmetic $>\mathrm{t}$ table means that there is a significant influence of political channel variables (X13) on public opinion (Y). It can be concluded, there is a significant influence of the independent variable of political channels on the dependent variable of public opinion in Tulungagung Regency at a real level of 5\%. The level of confidence regarding the influence of political channels on public opinion is listed in Table 4, obtained a coefficient of determination of 0.356 . That is, $36 \%$ of the average diversity of public opinion can be explained by political channels, while the rest are other factors that have not been included in the regression model.

Table 4 Coefficient Determination of Political Channels of Public Opinion

\begin{tabular}{ccccc}
\hline Model & R & R Square & Adjusted R Square & Std. Error of the Estimate \\
\hline 1 & $.596^{\mathrm{a}}$ & .356 & .354 & 6.408 \\
\hline
\end{tabular}

Then, the communicant variable X14 obtained sig $=0.000$ and $t$ arithmetic $=15,672$ while $t$ table $=1.96$. Because the value of sig $<0.05$ or $t$ arithmetic $>t$ table means that there is a significant influence of the communicant variable (X14) on public 
opinion (Y). It can be concluded, there is a significant influence of the independent variable of political channels on the dependent variable of public opinion in Tulungagung Regency at a real level of 5\%. The level of confidence regarding the influence of the communicant on public opinion is listed in Table 5, obtained a coefficient of determination of 0.728 . That is, $73 \%$ of the average diversity of public opinion that can be explained by the communicant, while the rest are other factors that have not been included in the regression model.

Table 5 Coefficient of Communicative Determination of Public Opinion

\begin{tabular}{ccccc}
\hline Model & R & R Square & Adjusted R Square & Std. Error of the Estimate \\
\hline 1 & $.854^{\mathrm{a}}$ & .728 & .728 & 4.159 \\
\hline
\end{tabular}

Testing the joint influence of political communicators, political messages, political channels and communicants on public opinion is recorded in Table 6. Obtained sig $=0,000$ and $\mathrm{F}$ arithmetic $=591.63$ while $\mathrm{F}$ table $=0.177$ Because the value of sig $<0.05$ or $\mathrm{F}$ arithmetic $>\mathrm{F}$ table, then reject Ho That is, there is a significant influence on the independent variables of political communicators, political messages, political channels and communicants together on the public opinion in Tulungagung Regency at the 5\% level.

Table 6 Joint Testing with ANOVA

\begin{tabular}{llrrrrr}
\hline & \multirow{2}{*}{ Model } & Sum of & df & Mean Square & F & \multirow{2}{*}{ Sig. } \\
\hline 1 & Regression & 21731.743 & 4 & 5432.936 & 591.634 & .000 \\
& Residual & 3627.257 & 395 & 9.183 & & \\
& Total & 25359.000 & 399 & & & \\
\hline
\end{tabular}

The level of confidence in the regression model that is built or the level of diversity of the dependent variable that can be explained by the independent variable is reflected in the coefficient of determination (R2).

Table 7 Coefficient Determination of Joint Influence

\begin{tabular}{ccccc}
\hline Model & R & R Square & Adjusted R Square & Std. Error of the Estimate \\
\hline 1 & $.926^{\mathrm{a}}$ & .857 & .856 & 3.030 \\
\hline
\end{tabular}

Based on Table 7, the coefficient of determination is obtained for 0.857 . This means that $86 \%$ of the average diversity of public opinion that can be explained by political communicators, political messages, political channels and communicants together influences public opinion, while the rest are other factors that have not been included in the regression model, namely the belief that one day The elected regent will lead Tulungagung Regency again. 


\section{DISCUSSION}

\section{The Influence of Political Communicators on Public Opinion About the Victory} of the Regent and Deputy Regent of Tulungagung Regency

According to the synthesis of political communication theory, political communicators are people who can provide information about things that contain meaning about politics. For example, candidates for Regent and Deputy Regent of Tulungagung in carrying out their campaigns are able to influence public opinion of Tulungagung. There are three categories of political communicators, namely politicians, activists and opinion leaders. Politicians are professional communicators in politics who translate the attitudes, knowledge and interests of a community. Whereas activists and opinion leaders as part-time communicators are able to convince others to think and act the same as him. Besides that, a political communicator must have credibility. Credibility is a set of communicative perceptions about the nature of communicators. Credibility is a communicative perception that is not inherent in the communicator. Credibility relates to the nature of communicators. Credibility relates to the problem of perception, hence credibility changes depending on the perpetrators of perception (communicates), the topics discussed, and the situation (Rachmat, 2008: 257). The most important component of credibility is expertise and trust. Expertise is a communicant's assessment of the communicator's ability, intelligence, experience. Communicators who are considered to have high expertise will usually be more appreciated. Trust is the communicant's impression of the communicator's character. Communists will usually judge whether the communicator has an honest, sincere, polite and ethical nature (Rachmat, 2008: 260).

Candidates for Regent and Deputy Regent of Tulungagung have good credibility so that they are able to change the attitudes and behavior of voters during the election in Tulungagung Regency because they have credibility as a political communicator. This is consistent with research conducted by Haidir Fitra Siagian (2012) that one of the important variables influencing changes in the attitude of message recipients is the credibility of the communicator. If a political communicator has a high level of credibility in the eyes of the public, then it will facilitate the process of transferring ideas, ideas, and political messages.

The political communicator of the candidates for regent and vice regent of Tulungagung was able to deliver to the throne of the Regent and vice regent of Tulungagung. Thus, it can be concluded, that the political communicator of candidates for regent and deputy regent influences public opinion of Tulungagung Regency.

\section{The Influence of Political Messages on Public Opinion About the Victory of the Regent and Deputy Regent of Tulungagung Regency}

The political message must in essence convince and arouse the masses, social authority, personal expression and public discussion. The campaign of candidates for regent and vice regent of Tulungagung must be able to convince and raise the public both personally or in groups. That is, if the prospective regent and deputy regent is able to convey political messages properly it will be able to influence public opinion Tulungagung. Based on quantitative information and theory, the 
researcher concludes that political messages have a positive and significant influence on public opinion in Tulungagung because the political messages conveyed by them represent the wishes and needs of the Tulungagung Regency, such as promises delivered by this couple can be said to be realistic and is a superior message product., as according to the needs and interests of the people of Tulungagung Regency, such as free school uniforms, Dr. Regional Iskak The achievement of hospitals that reach internationally, and meet the basic needs of the community is a major problem that is launched every day. In addition, Syahri Mulyo's profile is popular and is an expert in communicating with the public because he does not hesitate to go directly to the field to communicate with people who need help

\section{The Influence of Political Channels on Public Opinion About the Victory of the Regent and Deputy Regent of Tulungagung Regency}

The mass media or channel is a tool used to convey political messages, whether television, radio or online media, such as Facebook has the most essential political effects in political communication in the context of forming positive public opinion and the occurrence of victory in elections. This means that the use of the right mass media by prospective regents and vice regents of Tulungagung is able to convey political messages effectively so that they can influence Tulungagung people's opinion. This is consistent with what was done by Eko Susanto (2013 as stated earlier, which states that the use of mass media such as print media, electronic media and online media, is effective for spreading political messages so that they can reach heterogeneous and very target audiences With this function, the media is able to supply the information needs of the audience.Other research conducted by Raden Mas Jerry Indrawan (2017) shows that in this digital age the media is the most effective way to shape public opinion.In addition, public participation and involvement in politics also influenced by the process of political communication and public opinion circulating among them.

From quantitative information and theory, the researcher concludes that in this study political channels have a positive and significant influence on public opinion about the Victory of the Regent and Deputy Regent of Tulungagung Regency.

\section{Influence of audiences on public opinion About the victory of the Regent and Deputy Regent of Tulungagung Regency}

Political talks aimed at the communicant (audience) as targets in carrying out political campaigns have different social, cultural and economic characteristics that must be carefully calculated and planned programs must use appropriate communication strategies. In the process of conveying political messages either directly through public gatherings or through mass media or channels with the aim of creating positive public opinion. This means that good political talks between candidates for regent and deputy regent can have a positive effect on Tulungagung public opinion. From quantitative information and theory, the researcher concludes that in this study the communicant has a positive and significant influence on public 
opinion about the Victory of the Regent and Deputy Regent of Tulungagung Regency

\section{Joint Influence of Political Communicators, Political Messages, Political and Communicating Channels on the Victory of the Regent and Deputy Regent of Tulungagung Regency}

Public opinion as a political effect is formed through a process of political communication that starts from the opinion of each individual. Public opinion is a collection of individual views, attitudes, and beliefs about a particular topic, expressed by a significant proportion of a community. Thus, public opinion can be used and understood as a statement or problem that is controversial and opinions must be expressed in order to be responded to by the public through the process political communication includes political communicators, political messages, political channels and communism. Quantitative information and theory, enough to convince researchers to conclude that political communication has a positive and significant influence on public opinion about the Victory of the Regent and Deputy Regent of Tulungagung Regency Previous research conducted by Susanto on the Dynamics of Political Communication in the General Election (2013) states that in political communication, the most realistic fact to be used as a measure of success in conveying messages, is the increasing number of audiences who agree on what message is conveyed, the addition of followers and the number of hearings can be formed through opinions formed by political communicators, in this case the pair of Regent and Deputy Regent of Tulungagung has a strong influence in the eyes of the wider community. In addition, the results of previous research conducted by Raden Mas Jerry Indrawan (2017) that political communication by the political elite will not run optimally without establishment $\mathrm{n}$ public opinion. The popularity of political candidates will not increase if it is not supported by significant public opinion towards them. Therefore, political communication and public opinion have a close relationship because they both support each other. Thus it can be said, that the theory used in this study is proven to support this research.

\section{CONCLUSION}

Based on the results of the hypothesis test and discussion it can be concluded that: (1) There is a significant positive influence on political communicators on public opinion about the victory of the Regent and Deputy Regent of Tulungagung Regency. , (2) There is a significant positive influence between political messages on public opinion, (3) There is a significant positive influence between political channels on public opinion about the victory of the Regent and Deputy Regent of Tulungagung Regency, (4) There is a significant positive influence between the communicant public opinion about the victory of the Regent and Deputy Regent of Tulungagung Regency, and (5) There is a significant influence among communicators, political messages, political channels and communicants together on public opinion about the victory of the Regent and Deputy Regent of Tulungagung Regency. The findings from the research are other factors that are not examined, namely interpersonal communication, public trust or belief that if you run again as Regent of Tulungagung will lead and develop Tulungagung Regency 
in a better direction. Therefore it is suggested to other researchers to research with different theories and research methods

\section{BIODATA}

Erna Sugiarti SE works as an expert staff member of the Indonesian Democratic Party of Struggle 2019 and is currently continuing the Postgraduate Masters Program in Communication Studies at the InterStudi College of Communication Studies, Jakarta Indonesia

Poppy Ruliana, Dr. Dra., MSi works as a lecturer in LLDIKTI Region III of DKI Jakarta and is employed in the Postgraduate Program, Masters in Communication Sciences, InterStudi Communication College, Jakarta Indonesia

Irwansyah, Dr, MA as a lecturer in the Department of Communication, Faculty of Social and Political Sciences, University of Indonesia, Jakarta, Indonesia

\section{REFFERENCES}

Arifin Anwar. 2008. Public Opinion. Jakarta: Indonesian Library Publisher

Bakir, V. (2013). Torture, Intelligence and Sousveillance in the War on Terror: Agenda - Building Struggles. Farnham: Ashgate. p. 3. ISBN 9781472402554.

Denton R.E., Woodward G.C. (1998). Political Communication in America. New York: Praeger. p. 11. ISBN 978-0275957834.

Effendy, Onong Uchjana. 2006. Communication Theory and Practice. Bandung: Teen Rosdakarya.

Hay, C., (ed.), (2010). New Directions in Political Science: Responding to the Challenge of an Independent World A series of astute reflections on the nature, extent and implication of global interdependence for politics and a variety of political issues.

Iswandi, 2018. Public Opinion, Concepts, Formation and Measurement. Bandung: Simbiosa Rekatama

Kerlinger. 2006. Behavior Research Principles. Issue 3, Prints 7. Yogyakarta: Gadjah Mada University Press

McNair B. 2003. An Introduction to Political Communication, London: Routledge,

Rachmat, Jalaluddin. 2008. Psychology of Communication. Bandung: PT Remaja Rosdakarya

Rod Hague; Martin Harrop (2013). Comparative Government and Politics: An Introduction. Macmillan International Higher Education. pp. 1-. ISBN 978$1-137-31786-5$

Ruliana, Poppy.2016 Organizational Communication Theory and Case Studies. Second Edition, Jakarta: RajaGrafindo 
Sugiyono (2017). Quantitative, Qualitative, and R\&D Research Methods. Bandung: Alfabeta, CV

Swanson, D. \& Nimmo D. 1990, "New Directions in Political Communication: A Resource Book." Thousand Oaks: Sage,

Journal

Eko Harry Susanto, 2013. The Dynamics of Political Communication in General Elections. Journal of Communication Studies, Volume 1, Issue 2

Indrawan, Raden Mas Jerry 2017. Impact of Political Communication and Public Opinion on Community Behavior. Science Jutal Discourse Science 1 Communication. Volune 15 No. 2

Scheufele, Dietram A; Moy, P (2000) "Twenty-five years of the spiral of silence: A conceptual review and empirical outlook", International Journal of Public Opinion Research, 12 (1): 3-28, doi: 10.1093 / ijpor / 12.1.3 , ISSN 09542892.

(2007), "Opinion climates, spirals of silence, and biotechnology: Public opinion as a heuristic for scientific decision making", in Brossard, D; Shanahan, J; Nesbit, TC (eds.), The public, the media, and agricultural biotechnology: An international casebook, Cambridge, MA: Oxford University Press, pp. 231-41

Siagian Fitra Haidir, 2012. The Influence of the Credibility of Political Communicators to Get the Support of Audiences in the Election Journal Da'wah Tabligh, Vol. 13, No. 2, December 2012: 281 - 291

\section{Electronic/Internet Source}

http://journal.unhas.ac.id/index.php/kareba/article/view/593/416

Journal of European Public Policy Volume 22, 2015 - Issue 2: European integration in times of crisis: theoretical perspectives

"Political| Definition of Political by Merriam-Webster". Merriam-webster.com. Retrieved 25 February 2018.

https://www.tempo.co/tag/bupati-tulungagung

https://nasional.tempo.co/read/1130173/5-fakta-kasus-korupsi-bupatitulungagung-syahri-mulyo 